Article

\title{
The Imposition of the Death Penalty on Mexican Nationals in the United States and the Cultural, Legal and Political Context
}

\section{James Michael Olivero}

Department of Law and Justice, Central Washington University, Farrell Hall, Ellensburg, WA 98926, USA; E-Mail: olivero@cwu.edu; Tel.: +1-509-945-7185; Fax: +1-509-963-3205

Received: 5 February 2013; in revised form: 7 March 2013 / Accepted: 11 March 2013 /

Published: 20 March 2013

\begin{abstract}
This paper reviews death penalty perspectives from the United States, Mexico and international law. The United States practices the death penalty on not only its citizens, but those of other nations who commit capital crimes. Mexico is a death penalty abolitionist state that takes significant issue with the United States over executing Mexican nationals. The paper analyzes the cultural, legal and political conflict between the two countries surrounding the application of the death penalty on Mexican nationals.
\end{abstract}

Keywords: death penalty; capital punishment; Mexico; International Court of Justice; Avenda

\section{Introduction}

The United State remains a country that allows for the death penalty. In 2011, there were 43 executions in the United States, the only country in the North or South American continents to carry out any executions that year [1]. China, Iran, Saudi Arabia, Iraq and the United States led the world in executing prisoners in 2011, accounting for 93\% of all known executions in the world [2]. The United States will not only implement the death penalty against its own citizens, but also those of foreign nationals who commit capital level crimes while in the United States [3,4]. Since the re-imposition of the death penalty in the United States in 1976, 28 foreign nationals have been executed from around the world, including foreign nationals from the Dominican Republic, Mexico, Cuba, Paraguay, Honduras, Vietnam, Thailand, Germany, Philippines, Canada, South Africa, Iraq, Cuba and Pakistan. While there have been executions of foreign nationals from around the world, the majority came from Mexico, and the sentence was most likely imposed in the state of Texas [5]. The death penalty in the United States has been characterized as racist in nature. Since being reinstated in 1976, the death penalty has been primarily inflicted upon racial and ethnic minorities, such as 
Hispanics. The state of Texas, which joins the country of Mexico at its southern border, has a tenacious tradition of the imposition of the death penalty on citizens of the United States in general, Hispanic citizens of the United States, as well as the execution of Mexican nationals [4]. In 2011, there were approximately 51 Mexican nationals on death row in the United States [6].

Mexico has taken issue to the use of the death penalty against Mexican nationals in the United States. The imposition of the death penalty on Mexican nationals in the United State is an impediment to positive international relations between the two countries. Mexican nationals are the largest number of foreign nationals now on U.S. death rows, mostly in the state of Texas. Mexico believes that the death penalty in the United States is applied to Mexican nationals in a capricious manner and supports the government's assistance to condemned Mexican nationals [7]. Due to its opposition to the death penalty, Mexico refuses to extradite people to the United States who may face the death penalty or life in prison without the possibility of parole. As such, Mexico serves as a safe harbor to suspects of capital crimes in the United States out of concern for the death penalty [4].

\section{Mexico and the Death Penalty}

Traditionally, Mexico has limited the use of the death penalty. In the late 1700s, only a panel of judges had the authority to impose the death penalty in particular on a person convicted of a crime. In 1837, provisional judicial administration law established mandatory procedural and sentencing reviews in all capital cases. In 1857, the constitution called for a conditional abolition of the death penalty [8]. In 1929, Mexico's penal code abolished capital punishment in the federal district and territories [9], followed by all of Mexico’s thirty-one states. Progressive legislators struck the death penalty from Mexico's Revolutionary penal code of 1929 and received international acclaim. The new state strove to move away from retributive justice to redemption [10].

From 1942 to 1945, the president used his assumption of emergency powers during Mexico’s involvement in World War II to mandate the death penalty for a wide variety of offenses committed anywhere in the national territory. Common criminals found themselves condemned to death by federal judges in cases for crimes that neither resulted in the death of their victims, nor carried the death penalty in the regular criminal statutes where they were committed. A presidential pardon remained the only recourse for the condemned. Of the 83 offenders sentenced to death, the state only executed perhaps four. The president commuted the sentences of the vast majority of those convicted under the 1943 decree, addressing popular calls for vengeance and elite invocations of progressive principle [11].

Until recently, Mexico's Constitution allowed for the implementation of the death penalty in Mexico. Once in a while, death sentences were handed down by military tribunals, but none has been carried out since the 1960s. There have been calls for restoration of the death penalty in Mexico as the result of rising crime rates, in particular, instances of kidnapping by drug cartels. In Mexico City in 2001, the Partido Revolucionario Institucional (PRI) supported reinstating capital punishment as a deterrent mechanism to high crime rates and kidnapping, especially kidnapping [12].

In 2004, there was a huge protest rally with hundreds of thousands of people in Mexico City calling for a return to the death penalty as an answer to crime [12]. However, in December of 2005, the death penalty was abolished in all penal codes (federal and local) through reforms to Articles 14 and 22 of 
the Mexican Constitution. The Senate of the Republic passed a constitutional reform that explicitly prohibited the death penalty in Mexico. The Chamber of Deputies ratified the reform in June 2005 [4]. There were calls to reinstate the death penalty again in 2009 in response to public outcry over murders and notorious kidnappings associated with vicious and violent drug cartels. Anger and frustration over rampant killings and kidnappings ignited a debate over legalizing the death penalty. Much of the bloodshed was related to Mexico's drug war, as government forces cracked down on powerful traffickers and traffickers battled one another over pieces of the lucrative trade. However, violence spilled over into ordinary society [13].

The Green Party and PRI Governor, Humberto Moreira, asked Mexico’s Congress to reform laws pertaining to the death penalty that allowed for the execution of kidnappers that murdered their hostages. Mexico's Congress began a debate, but nothing was resolved, and some believe that it was just an attempt to secure votes and not an actual solution to stop crime [14]. Calls for the re-imposition of the death penalty were met with significant resistance from politicians, members of the Catholic Church [2] and Pope Benedict XVI [15]. Legal experts in Mexico suggest that there is no possibility of re-implementing the death penalty in Mexico [13].

\section{Execution of Mexican Nationals in the United States}

The United States has agreed to various protections afforded foreign citizens in the United States accused of crimes. Mexico has undertaken vigorous attempts to not only require the United States to abide by its agreements, but to prevent the executions of Mexican nationals in the United States. This has been met with limited success, leading to protests by the Mexican government and condemnation on the international level. The state of Texas is well ensconced in the practice of executing offenders convicted of capital crimes, regardless of the wishes of the international community, Mexico in particular, and seems oblivious to intervention by the federal government, defying efforts by both Presidents Bush and Obama.

\subsection{The Vienna Convention}

The United Nations convened the Conference on Consular Relations (The Vienna Convention) on 24 April, 1963 attended by ninety-two nations. The subsequent treaty standardized consular law, including consular rights, privileges and duties. The United States Senate ratified both the Vienna Convention and the Optional Protocol Concerning the Compulsory Settlement of Disputes in 1969. Article 36 of the treaty deals with communication and contact with foreign nationals in the receiving state and requires that the receiving state notify a detained or imprisoned foreign national of his right to contact his consular post without delay [16]. Mexico has an extensive and increasingly sophisticated program of consular assistance to Mexican nationals residing in the United States. In the early 1980s, the Mexican government stepped up consular officer services to provide protection, due to the increased number of Mexican nationals facing death sentences. In 1981, the Mexican Foreign Ministry created consular protection officers whose purpose was to protect the rights of Mexican nationals out of the country. In 1982, the Mexican government enacted the Governing Law of the Mexican Foreign Service, governing the actions of consular officers in foreign nations, the most important being the obligation to protect the rights of Mexican nationals on death row or capital 
cases. These included assisting Mexican nationals in their relations with local authorities, advising nationals of their rights and obligations, visiting detainees in prisons and representing those Mexicans who cannot defend their own interests. In 1986, the Mexican Foreign Ministry established a Program of Legal Consultation and Defense that sent Foreign Service officers to American law schools to better assist attorneys representing Mexican nationals in capital cases [17].

\subsection{Early Treaty Success for Mexico}

In 1985, the practice of abducting suspected criminals and returning them to the United States became commonplace. In June 1989, Texas police officers kidnapped Hector Morales Villa and Omar Ayala Mendoza in Mexico and brought them to the United States to face capital murder charges. Neither of the accused was advised of their right to contact the Mexican consular post. The Mexican consulate assisted the defense attorney in preparing a writ of habeas corpus, stating that their confinement violated the Treaty of Extradition Treaty. Under the treaty, Mexico refused to extradite suspects without an assurance from prosecutors that the death penalty would not be sought. After significant diplomatic pressure, one defendant was granted a life sentence and the other a sixty year sentence in exchange for guilty pleas. Ricardo Aldape Guerra, an undocumented Mexican migrant, was given a death sentence for the murder of a white, Houston, Texas, police officer in 1982. Aldape was charged with capital murder and sentenced to death, despite evidence that he was not the shooter. His conviction was upheld on appeal, and the United States Supreme Court denied his writ for certiorari. The Mexican consular post and lawyers obtained previously undiscovered evidence. With the aid of a pro bono law firm, Aldape filed a federal writ of habeas corpus alleging multiple constitutional due process violations, and an indefinite stay was granted. The federal district court concurred with Aldape's due process arguments and charged police and prosecutors with misconduct, and the decision was affirmed by the Fifth Circuit Court of Appeals. The prosecution decided not to retry the case, and Aldape was released, returning to Mexico as a hero. He spent 15 years in a maximum security prison in Huntsville, Texas, before his death sentence was overturned and he was set free $[4,17]$.

\subsection{Early Failures by the United States Fails to Abide by the Vienna Convention}

In 1983, Ramon Montoya Facundo was convicted of capital murder and sentenced to death in the state of Texas. The Mexican Foreign Ministry aided his defense. His efforts to appeal his conviction and sentence was fruitless, and Facundo was executed. He became the first Mexican national executed in the United States since the United States reinstated the death penalty in 1976. The Mexican government dispatched foreign-service officers to the United States to defend the rights of Mexican foreign nationals detained in the United States. Further, the National Commission of Human Rights previously documenting human rights abuses in Mexico began to review all death sentences involving Mexican nationals in the United States. In 1989, Irineo Tristan Montoya, a Mexican national, was executed in Texas. Tristan unsuccessfully appealed his convictions despite not having been granted his right to contact consular officers. As the execution date approached, Mexico protested the Article 36 violation. Texas officials responded that Texas was not a signatory to the Vienna Convention. In May 1997, United States President Clinton and Mexican President Ernesto Zedillo pledged to honor the 
Vienna Convention and to provide better consular protection for Mexicans within the United States. However, Texas Governor George W. Bush denied a stay based on the notification violation and Tristan Montoya was put to death [17]. In 1997, Mario Benjamin Murphy, a Mexican citizen, was executed by lethal injection in the state of Virginia as the result of a murder for hire conviction. Murphy filed his federal habeas petition on April 30, 1996, claiming, among other things, that both his conviction and death sentence were constitutionally invalid, because the Virginia Beach authorities failed to notify him that, as a foreign national of Mexico, he had a right under the Vienna Convention on Consular Relations to contact the consulate of Mexico; as such, the violation of the Vienna Convention rendered his guilty plea involuntary. The Fourth Circuit Court of Appeals ruled that even if the Vienna Convention on Consular Relations could be said to create individual rights (as opposed to setting out the rights and obligations of signatory nations), it certainly does not create constitutional rights. Further, Murphy failed to establish prejudice from the alleged violation of the Vienna Convention, because he did not explain how contacting the Mexican consulate would have changed either his guilty plea or his sentence [18]. Mexican citizen, Miguel Angel Flores, was executed in Texas on November 9, 2000 for capital murder. Flores was not informed of his consular rights, and the Mexican government did not receive notice until after he had been sentenced to death. The Fifth Circuit reviewed Flores' appeal and cited its previous decision in Faulder v. Johnson. In Faulder, there had been a violation of Faulder's Vienna Convention rights; however, the omission was a harmless error that did not merit reversal. The Supreme Court of the United States refused to intercede. The U.S. State Department asked Texas for a consideration of clemency, and Mexico, France, Argentina, Spain, Switzerland and Poland sent letters as well. Texas Governor Bush did not provide him a reprieve, and he was executed [19].

\subsection{Mexico Successfully Saves a Mexican National from the Death Penalty}

The Mexican government learned of Gerardo Valdez Maltos, a Mexican citizen, who was scheduled for execution on April 2001, just two months before the execution date. The Mexican Capital Legal Assistance Program, designed to provide assistance to Mexican nationals with death sentences in the United States, hired neuropsychologists, who found that Valdez suffered from severe brain damage and that this evidence was never presented to the jury at trial. The Oklahoma Pardon and Parole Board recommended clemency as a result, and the Governor refused. The Mexican Government, along with the Mexican Capital Legal Assistance Program, submitted a letter to Oklahoma Governor Frank Keating urging him to adopt the clemency recommendation of the Oklahoma Pardon and Parole Board, and he issued a stay of execution. The U.S. State Department sent the Governor a letter asking him to consider the ruling of the International Court of Justice in the LaGrand matter and whether the case was prejudiced by the violation of Vienna Convention treaty rights. Walter and Karl LaGrand were German citizens sentenced to execution in Oklahoma who had not been granted access to the German consulate. Karl LaGrand was executed. Walter LaGrand sought a stay in his execution through the United States Supreme Court and the International Court of Justice. The Supreme Court refused to hear the matter. The International Court of Justice issued an order instructing the United States not to execute LaGrand and that it had jurisdiction, because the United States and Germany were signatories to the Optional Protocol of the Vienna Convention. Despite this, 
LaGrand was executed. The International Court of Justice went on to find that it had jurisdiction and affirmed the binding nature of the Optional Protocol to the Vienna Convention on the United States. As such, LaGrand's execution violated the Vienna Convention, and its breach violated the rights of Germany under the treaty and Karl and Walter LaGrand as per their individual rights [17,20,21]. After review, the Governor was not swayed and set the matter to go on for execution. He then issued another stay to allow Mexico to evaluate legal and diplomatic alternatives available to them, and Valdez granted the novel legal issues in the case. Valdez appealed to the Oklahoma Court of Criminal Appeals. In September 2001, the court granted an indefinite stay of execution concerning serious matters of novel legal issues and international law [20,22].

\subsection{The United States Violates the Vienna Convention and the Finding of the International Court of Justice}

In 2002, Javier Suarez Medina, a Mexican citizen, was executed by the state of Texas for murdering a police officer. Although Medina was a Mexican national, the Texas authorities never informed him of his consular rights or notified Mexican officials in violation of Article 36 of the Vienna Convention. The Mexican government used diplomatic pressure and legal options, including a reprieve, while he filed his case with the International Court of Justice. Mexican President Vicente Fox pled with Texas Governor Rick Perry to suspend the death sentence. The Mexican Congress passed a joint resolution asking Governor Perry and President Bush to intervene. The Mexican government pressured the U.S. Department of State and demanded compliance with international obligations and adopted the Optional Protocol to the Vienna Convention, allowing Mexico to petition the International Court of Justice in future cases. The U.N. High Commissioner of Human Rights, Mary Robinson, asked Secretary of State, Colin Powell, to intervene. Argentina, Brazil, Chile, Colombia, El Salvador, Guatemala, Honduras, Panama, Paraguay, Uruguay, Venezuela, Poland and Spain filed briefs stating that the United States had violated the Vienna Convention and the execution would violate the Provisional Order of the Inter-American Court on Human Rights and the LaGrand decision in the International Court of Justice. The United States Supreme Court refused to hear his appeal. After the execution, Mexican President Vicente Fox cancelled a trip to meet with Texas Governor Rick Perry and President Bush at the President's Crawford ranch [17].

In 2003, the International Court of Justice heard Avena and Other Mexican Nationals (Mexico $v$. United States of America). The court required the United States to take all measures necessary to prevent the executions of Cesar Roberto Fierro Reyna, Roberto Moreno Ramos and Osvaldo Torres Aguilera, until the court could investigate allegations of violations of Article 36 of the Vienna Convention on Consular Relations. In 2004, The International Court of Justice found that the United States had breached its obligations by failing to notify 51 Mexican nationals of their rights under the agreement or notifying the Mexican government. In doing so, the United States had deprived Mexico of its rights to access, etc., with Mexican nationals held in the United States. Further, the United States had violated the rights of Reyna, Ramos and Aguilera by not reviewing and reconsidering their sentences in light of the breeches. It ordered the United States to review and reconsider their sentences in light of the breeches [23-26]. 
Only one of the identified Mexican prisoners has had his sentence commuted. Oklahoma agreed to life in prison without parole as a result of the finding of the International Court of Justice in Avena, while Texas indicated that it would go with the executions as scheduled [27]. Two months after Avena, Oklahoma Governor George Henry commuted Torres' sentence to life without possibility of parole. Governor Henry recognized that the state had violated Torres's rights under the Convention and that compliance with the treaty is important for the protection of U.S. citizens arrested abroad [28]. Cesar Fierro and Robert Ramos are currently being held on death row at Polunsky Prison in the state of Texas [29]. Fierro may be executed despite the discovery of compelling evidence found, in part, by the Mexican government that he did not commit the murder for which he was sentenced. United States officials never notified the Mexican government of his detention. As a result of the delay, Mexican consular officials did not discover strong evidence that police coerced Fierro's written confession until more than a decade after a jury used it to impose the death sentence. Fierro was never informed of his rights to contact the Mexican consulate and avail himself of the important services only consulates can provide to protect their nationals in criminal matters. Communication with his consulate and the evidence it could have procured may have prevented Fierro's death sentence and his eventual execution [30].

\subsection{The United States Continues to Execute Mexican Nationals in Spite of Protests}

Jose Ernesto Medellin, a Mexican national, was convicted and sentenced to death for the rape and murder of two teenage girls in 1993. In spite of the Oklahoma Court of Criminal Appeals decision granting a temporary stay of Torres's execution, the Fifth Circuit denied Medellin's petition, and the execution date moved forward. Medellin petitioned and was granted a writ of certiorari with the U.S. Supreme Court [31]. Before the court could hear the case, President George W. Bush issued a memorandum to the U.S. Attorney General ordering states to review convictions of foreign nationals who had not been advised of their rights under the Vienna Convention. The U.S. Supreme Court then dismissed Medellin's case as a moot issue. Medellin then filed a second case in state court for habeas corpus relief based on President Bush's memorandum.

Less than two weeks later, the United States withdrew from the Optional Protocol to the Vienna Convention on Consular Relations, which gave the International Court of Justice jurisdiction over Vienna Convention claims. As such, the United States no longer availed itself of the International Court of Justice jurisdiction to interpret and apply the Vienna Convention [23,32]. President Bush requested a review of the Medellin's case, and Texas refused [31]. The Texas Courts dismissed his petition, and the U.S. Supreme Court granted certiorari a second time. The Supreme Court refused to require Texas to comply with Avena and President's Bush's memorandum. The execution was delayed several hours by a last-minute appeal to the U.S. Supreme Court, which rejected a stay. Texas Governor Rick Perry did not halt the execution, and Medellin was executed on August 5, 2008. The Supreme Court held that the International Court of Justice judgment in Avena was not binding federal law [33]. The International Court of Justice in The Hague ruled that the United States violated its 2004 ruling when Texas executed Medellin. The International Court of Justice again ordered the United States to review the cases of the remaining Mexicans facing the death penalty [34-36]. The Supreme Court refused to act, even while agreeing that the Avena decision constitutes an international law obligation on the part of the United States [37]. 
The Obama administration was aware of the conflict between the International Court of Justice and the United States remaining an ongoing problem and that other Mexican nationals still awaited execution in Texas and did nothing. Congress was not asked to implement the International Court of Justice, even though the Supreme Court had made clear that this action was necessary. In July 2011, Humberto Leal Garcia, another of the Mexican nationals covered under the Avena decision, faced execution in Texas [32,37]. Humberto Leal Garcia was found guilty for the rape and murder of 16-year-old Adria Sauceda. Texas law enforcement officers failed to notify Garcia, along with fifty one other Mexican nationals, of their right to access their consulate after arrest. Leal petitioned the Supreme Court based upon a pending bill in the Senate, which would create the prerequisite authority for honoring the International Court of Justice mandate. The Obama administration, in an amicus brief to the Supreme Court, supported Leal [38]. At the same time, the Supreme Court refused to delay the execution, because of pending legislation and a lack of congressional action on the bill was imminent [37]. The State of Texas executed Leal by lethal injection on the evening of 7 July, 2011. He became another foreign national denied access to their national consulates in violation of the Vienna Convention on Consular Relations [38]. What made this case different is that the Supreme Court denied his petition to stay his execution, despite the fact that a bill, titled the Consular notification Compliance Act of 2011, had been introduced into Congress, which would have provided him with a claim to challenge his capital sentence, if voted in [39].

\section{Conclusions and Discussion}

The Mexican government has raised international awareness regarding repeated violations of the consular notification provisions of the Vienna Convention by the United States. The United States has remained impervious to international pressure concerning abuses of the Vienna Convention out of concerns for state rights to uphold their criminal laws, federal impotence to control state action and the judiciary's unwillingness to recognize the force of international treaty obligations and routine failures to notify the Mexican government or provide defendants with consular assistance rights [16]. The United States practices the death penalty and has become increasingly isolated from other industrialized countries as a death penalty hold out [4]. Mexican nationals are the largest number of foreign nationals now on U.S. death rows, mostly in the state of Texas [40]. Mexico believes that the death penalty in the United States is applied to Mexican nationals in a capricious manner and supports the government's support for condemned Mexican nationals [7]. Some argue that despite attention to violations of the Vienna Convention and subsequent protest from the International Court of Justice, as well as condemnation by Mexico and other countries, the strength of the evidence in these cases is overwhelming, and there is little standing to suggest that their cases were somehow prejudiced. For example, Humberto Leal Garcia raped and murdered sixteen-year-old Adria Sauceda in San Antonio in the spring of 1994, and the evidence was overwhelming. Subsequent to his conviction, he exhausted his appeals as he sought both state and federal post-conviction collateral relief in the same manner as a citizen of the United States. As such, the issues in these cases with respect to the Vienna Convention are not a violation of constitutional rights, but merely violations of a treaty [41].

On the other hand, others state that the violation of the Vienna Convention is more than a technicality. For example, lead counsel for Leal stated that the Mexican consulate would have 
provided experienced and highly qualified attorneys who would have challenged the prosecution's reliance on "junk" science to obtain a conviction and would have presented powerful mitigating evidence at the penalty phase, including expert testimony regarding Leal's learning disabilities, brain damage and sexual abuse at the hands of his parish priest [42,43]. This belief may be bolstered by the Gerardo Valdez Maltos case in 2001 [22]. The Mexican Foreign Ministry lawyer stated that the United States regularly assigns Mexican defendants public defenders who speak little or no Spanish and have no experience in death penalty cases. If the United States would follow the treaty, Mexican consulates would provide defendants with Spanish speaking lawyers who are well versed in U.S. capital cases.

In addition, Mexico is not supportive of the death penalty in the United States, as can be seen in the treaty on extradition [17]. In 2004, the state of California estimated that 360 persons wanted for murder and serious crimes had not been extradited from Mexico. Since 1980, the extradition treaty between the United States and Mexico has permitted Mexico to refuse to extradite citizens in the absence of assurances that the death penalty will not be imposed. Until two years ago, prosecutors in the United States sometimes agreed not to seek the death penalty to achieve extradition of fugitives in Mexico. In October 2001, the Mexican Supreme Court ruled that life imprisonment violated Mexico's constitution. Mexico interprets the treaty in the new light of the Supreme Court's decision. As such, prosecutors in the United States must waive the possibility of death and provide assurances of a determinate sentence. If a prosecutor in the United States officially requests extradition from Mexico and is denied, Mexico will prosecute the fugitive under its own laws and penalties, usually resulting in modest penalties [44-46].

The United States tells the world it has made sufficient efforts to educate law enforcement officers to comply with the Vienna Convention. In 2004, it pointed out that it had circulated 100,000 copies of a compliance manual and 600,000 pocket cards to local law enforcement officials. However, there were 700,000 law enforcement officials in the United States in 18,000 separate state and local jurisdictions. The State Department stated that the United States' attempts should be sufficient, given the size of the country [47,48]. Yet, in 2011 it appears that law enforcement agencies in major metropolitan areas are not aware of the need to secure the consular rights of foreign nationals. An article in Sheriff Magazine, associated with the National Sheriff's Association, lamented the fact that senior law enforcement personnel were not aware of the importance and the need to protect consular rights among arrested foreign nationals and that mandatory notification was a secret that should not be kept a secret [49].

A host of solutions have been suggested as answers, including improving educational measures at all levels of law enforcement, including police, lawyers and judges. In addition, the advisement of the right to consular assistance could be incorporated into the Miranda warning. However, this option is seen as likely to be met with resistance by law enforcement officials. If police fail to abide by consular rights, the district attorney should be responsible for ensuring that these rights are honored once the case is assigned to them and definitely before trial. The problem with this is that law enforcement may have already questioned the detained person. There exists a strong likelihood that the defendant would already be prejudiced by a confession or some other action that may be used as evidence of his guilt. To assure that the justice system enforces treaty rights, cases could be dismissed or evidence thrown out when officers fail to comply with consular rights [47]. 
The question of what to do about undocumented immigrants is a political controversy resulting in conflicting demands on law enforcement. For example, in October 2011, the Justice Department filed suit against South Carolina stating that South Carolina's requirement that the immigration status of arrested individuals be verified will lead to racial or language profiling, whereby individuals may be treated as non-citizens just because they do not speak English well. In 2010, the State Department published revised manual detailing instructions for federal, state and local law enforcement officials concerning appropriate procedures when dealing with foreign nationals in the United States. The manual recommends police officers to routinely ask every person arrested or detained whether he or she is a U.S. citizen. The State Department informs officers that unfamiliarity with English may indicate foreign nationality. In essence, while the State Department encourages local law enforcement officials to check the citizenship status of anyone arrested so that the U.S. can comply with treaty-provided consular access privileges, the Justice Department is suing to prevent local law enforcement officials from checking the citizenship status of anyone arrested [50].

The lack of compliance by law enforcement officers in the United States might also be traced beyond a mere a lack of training to a fundamental dislike of undocumented immigrants that is shared with the public. Support for the death penalty in the United States has been associated with crime fears [51,52]. The public is concerned about illegal immigrants from Mexico and associates them with crime. For example, fears about a mythical illegal immigrant crime wave helped to propel passage of a law in Arizona that made it a crime to be present in the state without legal documents. While the number of illegal immigrants increased in Arizona previous to the passage of this law, the rate of crime declined. On a national level, male noncitizens born in Mexico have much lower rates of institutionalization than the native-born. Men born in the United States have incarceration rates more than eight times higher [53].In another study, researchers found that recent undocumented immigrants had no significant effect on crime rates, and youth born abroad were less likely than native-born youth to be criminally active. Instead, undocumented immigrants have disproportionately been the victims of racial profiling, police brutality, crime and racist hate crimes [54]. Despite this, one city council candidate in the state of Washington campaigned on a platform suggesting that illegal immigrants should get the death penalty [55]. Many immigrants to the United States, especially Mexicans and Central Americans, are young men with very low levels of education. Popular stereotypes associate them with higher rates of crime and incarceration. The fact that they enter the United States through unauthorized means is seen as an assault against the rule of law, linking immigration and criminality. Since the early 1990s, as the undocumented immigrant population increased to historic highs, the rates of violent crimes and property crimes in the United States decreased significantly, in some instances to historic lows, yet the myth and connection between undocumented aliens and crime remains [56].

There seem to be deep cultural divisions on the death penalty between Mexico and the United States. While some surveys suggest support for the death penalty in Mexico [57,58], others do not [59]; the death penalty is not constitutional or supported by major political party power groups [57] human rights groups [60] and the Catholic Church. Mexico has been a powerful voice in international forums calling for the end of death penalty punishment [57]. Mexican legal experts state that it is unlikely if not impossible to reinstate the death penalty in Mexico, due to substantial legal obstacles. For example, in 1981, Mexico signed a human rights treaty as part of the Organization of American States that stated that once the death penalty was eliminated, it could not be revived [61]. In addition, Mexico has signed 
additional international treaties against the death penalty and human rights, including: the International Covenant on Civil and Political Rights; First Optional Protocol to the Covenant; Second Optional Protocol to the International Covenant on Civil and Political Rights; Convention on the Rights of the Child; Convention Against Torture and Other Cruel, Inhuman or Degrading Treatment or Punishment; American Convention on Human Rights; Protocol to the American Convention on Human Rights to abolish the Death Penalty; Inter-American Convention to Prevent and Punish Torture; and Statute of the International Criminal Court [62].

In the United States, the practice of executing offenders committing capital crimes is constitutionally supported, after a brief hiatus beginning in the late 1970s in which the United States Supreme Court found that the utilization of the death penalty was freakish and capricious in its application and violated the 4th and 8th amendments. Some states set about revising the process of condemning and executing prisoners to meet constitutional safeguards. In the United States, there are human rights organizations that challenge the death penalty, including the Catholic Church [63]. In 2010, 38 states had statutes allowing for the death penalty, as a growing number of states abolished the practice. This reduction seems to match reductions in public support for the practice. Support for the death penalty has been associated with fear of crime. It appears that crime fears in the 1980s fueled support for the death penalty through the 1990s. For example, in 1991, 76\% of citizens in the United States supported the death penalty for murder. It began to drop in 2006, where 67\% now supported the death penalty [4,64]. In 2012, Proposition 34 would have removed the death penalty from criminal statutes in California, but it was defeated by a narrow margin. The vote exemplified a growing lack of support for the death penalty. In 1978, $71 \%$ of California voters supported a proposition that reinstituted the death penalty. In the present vote, 53\% of California voters supported retaining the death penalty [65].

In a similar manner and related to the public's wavering support for the death penalty, the application of the death penalty has become more exclusive through United States Supreme Court rulings. For example, in 2005, in the case of Atkins $v$. Virginia, the Supreme Court found that the execution of a defendant with mental retardation constituted cruel and unusual punishment prohibited by the Eighth Amendment. The Court cited evolving standards of decency in its opinion, as exemplified by the large number of States prohibiting the execution of mentally retarded people, as well as a complete absence of legislation reinstating such executions [66]. In 1989, the Supreme Court in Stanford $v$. Kentucky found that despite evolving standards of decency, there was no national consensus against the execution of 16- and 17-year-old offenders and refused to reverse Stanford's death sentence based upon the argument that he was 17 years and four months old at the time of his capital offense [67]. However, in 2005, in the case of Roper v. Simmons, the Supreme Court reversed itself and found that it was a violation of the Eighth Amendment's evolving standards of decency concept and the Fourteenth Amendments to execute a juvenile offender who was older than 15, but younger than 18 when he committed a capital crime [67].

Foreign nationals from around the world, not just Mexico, were executed in the United States between 1976 and 2012. According to Human Rights Watch, between 1976 and February 2012, 28 foreign nationals were executed in the United States in the states of Florida, Louisiana, Virginia, Arizona, Oklahoma, Nevada and Texas. Their citizenships were in the Dominican Republic, Mexico, Cuba, Paraguay, Honduras, Vietnam, Thailand, Germany, Philippines, Canada, South Africa, Iraq, 
Cuba and Pakistan. The majority (28.5\%; $\mathrm{N}=8$ ) came from Mexico, and the sentence was imposed most often in Texas (39.2\%; $\mathrm{N}=11)$. All indications are that none of these executed individuals were informed by U.S. authorities upon arrest of their right to have their consulate notified of their detention, as required under Article 36 of the Vienna Convention on Consular Relations. There are records of unsuccessful appeals by some of these executed foreign national citizens for the state's failure to comply from foreign nationals from countries besides Mexico, including Canada, Germany and Paraguay. Table 1 below illustrates the citizenship of foreign nationals held on death row in the United States and the states or federal prisons in which they are located as of February 2013 [68].

Table 1. Foreign national citizenship on death row in state or federal prisons.

\begin{tabular}{|c|c|}
\hline $\begin{array}{l}\text { Foreign National } \\
\text { Citizenship on Death Row }\end{array}$ & State or Federal Prisons and Frequency \\
\hline Mexico & $\begin{array}{l}\text { Alabama }(\mathrm{N}=1) \text {, Arizona }(\mathrm{N}=1) \text {, California }(\mathrm{N}=38) \text {, Florida } \\
(\mathrm{N}=1) \text {, Georgia }(\mathrm{N}=1) \text {, Nebraska }(\mathrm{N}=1) \text {, Nevada }(\mathrm{N}=1) \text {, Ohio } \\
(\mathrm{N}=1) \text { Oregon }(\mathrm{N}=2) \text {, Pennsylvania }(\mathrm{N}=1) \text {, Texas }(\mathrm{N}=13)\end{array}$ \\
\hline Viet Nam & $\begin{array}{l}\text { Alabama }(\mathrm{N}=1) \text {, Arizona }(\mathrm{N}=1) \text {, California }(\mathrm{N}=38) \text {, Florida } \\
(\mathrm{N}=1) \text {, Georgia }(\mathrm{N}=1) \text {, Nebraska }(\mathrm{N}=1) \text {, Nevada }(\mathrm{N}=1) \text {, Ohio } \\
(\mathrm{N}=1) \text { Oregon }(\mathrm{N}=2) \text {, Pennsylvania }(\mathrm{N}=1) \text {, Texas }(\mathrm{N}=13)\end{array}$ \\
\hline El Salvador & $\begin{array}{l}\text { California }(N=2) \text {, Georgia }(N=1) \text {, Louisiana }(N=1) \text {, Texas } \\
(N=1) \text {, Virginia }(N=1) \text {, Federal }(N=1)\end{array}$ \\
\hline Honduras & California $(\mathrm{N}=3)$, Florida $(\mathrm{N}=1)$, Texas $(\mathrm{N}=2)$ \\
\hline Cambodia & California $(\mathrm{N}=3)$, Pennsylvania $(\mathrm{N}=1)$, Texas $(\mathrm{N}=1)$ \\
\hline Cuba & California $(\mathrm{N}=1)$, Florida $(\mathrm{N}=8)$, Nevada $(\mathrm{N}=1)$ \\
\hline Jamaica & Florida $(\mathrm{N}=3)$, Pennsylvania $(\mathrm{N}=1)$ \\
\hline Iran & Alabama( $(\mathrm{N}=1)$, California $(\mathrm{N}=1)$ \\
\hline Columbia & Florida $(\mathrm{N}=2)$, Federal $(\mathrm{N}=2)$ \\
\hline Canada & Montana $(\mathrm{N}=1)$, Federal $(\mathrm{N}=1)$ \\
\hline United Kingdom & Nevada $(\mathrm{N}=1)$, Texas $(\mathrm{N}=1)$ \\
\hline Guatemala & California $(\mathrm{N}=2)$ \\
\hline Tonga & Nevada $(\mathrm{N}=1)$ \\
\hline Serbia & Nevada $(\mathrm{N}=1)$ \\
\hline France & Louisiana $(\mathrm{N}=1)$ \\
\hline Russia & Federal $(\mathrm{N}=1)$ \\
\hline Lithuania & Federal $(\mathrm{N}=1)$ \\
\hline Ukraine & Virginia $(\mathrm{N}=1)$ \\
\hline Nicaragua & Texas $(\mathrm{N}=1)$ \\
\hline Argentina & Texas $(\mathrm{N}=1)$ \\
\hline Bangladesh & Texas $(\mathrm{N}=1)$ \\
\hline Jordan & Ohio $(\mathrm{N}=1)$ \\
\hline Lebanon & Ohio $(\mathrm{N}=1)$ \\
\hline Haiti & Pennsylvania $(\mathrm{N}=1)$ \\
\hline Armenia & Nevada $(\mathrm{N}=1)$ \\
\hline Spain & Florida $(\mathrm{N}=1)$ \\
\hline Costa Rica & Florida $(\mathrm{N}=1)$ \\
\hline
\end{tabular}


Table 1. Cont.

\begin{tabular}{l|l}
\hline Bahamas & Florida $(\mathrm{N}=3)$ \\
\hline Trinidad & Florida $(\mathrm{N}=2)$ \\
\hline Estonia & California $(\mathrm{N}=1)$ \\
\hline Peru & California $(\mathrm{N}=1)$ \\
\hline Philippines & California $(\mathrm{N}=1)$ \\
\hline Egypt & California $(\mathrm{N}=1)$ \\
\hline Germany & Arizona $(\mathrm{N}=1)$ \\
\hline Laos & California $(\mathrm{N}=1)$ \\
\hline China & California $(\mathrm{N}=1)$ \\
\hline
\end{tabular}

It appears that Texas executes citizens of the United States and Mexico on a prolific basis in comparison with other states. Texas will execute offenders and bristles at attempts to even adopt stays of executions imposed by international opinion and political pressures from Mexico and the federal government of the United States. President Bush as governor of Texas refused to allow stays of execution, and his pleas to hold off use of the death penalty by Texas as president were ignored [19,22]. Texans remain strongly in favor of the death penalty, with 73 percent either somewhat or strongly in support and only 21 percent opposed [69]. In 2012, nine new death sentences were handed down and 15 executions took place, three times more than any other state [70].

The Mexican approach to crime and punishment is distinctly different to that of the United States. My research on corrections in Mexico reveals strong cultural differences with that of the United States. The Mexican system of punishment is decidedly less retributive in nature than that of the United States. The Mexican criminal justice system sets down sentences that seem minimal by standards in the United States. The utilization of life sentences without the chance of parole is unconstitutional in Mexico [44,45]. When we compared prisons in the United States with that of Mexico, the Mexican prison system is much less retributive than that of the United States. For example, in Mexican prisons, contact with families is an accepted daily fact and is not constricted as it is in the United States, producing a relative state of calm and strengthening family ties. Children, women, indeed whole families walk fairly freely in Mexican prisons and spend the night on a regular and unscheduled basis. This is far from the case in the United States [46,71,72]. Mexican Catholic faith has played a defining role throughout their nation's history. Mexico is chiefly a Catholic country, and the Catholic Church has long opposed the use of the death penalty. The death penalty is viewed as a barbaric practice and counter to the historic and Catholic roots of the Mexican people. A 2010 census in Mexico revealed that $84 \%$ of the population professes to be Catholic [73]. The Roman Catholic Church has spoken out on public issues, including the death penalty, ignoring former constitutional bans on clerical involvement in Mexican politics. In 1992, constitutional changes allowed clerics to engage in political dialogue, leading to a resumption of diplomatic relations with the Vatican [74]. In 2009, in response to calls for the resumption of the death penalty as a means to control crimes committed by drug cartels, Pope Benedict XVI expressed joy that the Mexican government had eliminated the death penalty and recognized the right to life. Other members of the Catholic Church also spoke out against the proposal to reinstitute the death penalty, denouncing it as immoral and illegal [15]. A survey on attitudes concerning opposition to the legalization of euthanasia, same sex marriage, abortion and the death 
penalty found that the majority of Mexicans oppose these issues based upon Catholic principles [8,60]. Finally, the death penalty for Mexico may also serve symbolic purposes; Mexico has long been criticized for human rights violations, and the abolition of the death penalty serves as notice of its progress [71] and provides a contrast with the United States. In addition, the use of the death penalty in the United States against Mexicans may be symbolic of United States imperialism and Mexican subordinate treatment. It could be that the death penalty issue is a tool to bully the United States [18].

\section{References and Notes}

1. “The Death Penalty in 2011.” Amnesty International. Available online: http://www.amnesty.org/ en/death-penalty/death-sentences-and-executions-in-2011 (accessed on 18 March 2013).

2. Nicholas LaChappelle. "Placing the American Death Penalty in the Global Context: A Test of the Marshall Hypothesis." In Selected Works of Nicholas L LaChappelle. Available online: http://works.bepress.com/cgi/viewcontent.cgi?article=1000\&context=nicholas_lachappelle (accessed on 26 February 2013).

3. Alan Clarke, and Laurelyn Whitt. The Bitter Fruit of American Justice. Lebanon: Northeastern University Press, 2007.

4. Ricardo Ampudia. Mexicans on Death Row. Houston: University of Texas, 2010.

5. Mark Warren. “Foreign Nationals, Part II.” Death Penalty Information Center. Available online: http://www.deathpenaltyinfo.org/foreign-nationals-part-ii\#scheduled (accessed on 14 March 2013).

6. Adam Liptak. "Mexican Citizen Is Executed as Justices Refuse to Step in.” The New York Times, 7 July 2011. http://www.nytimes.com/2011/07/08/us/08execute.html.

7. Patrick Timmons. "The Memoria: Developments since the Conference and Useful Information.” In The Death Penalty and Mexico-U.S. Relations: Historical Continuities, Present Dilemmas: Conference Memoria. Edited by Patrick Timmons and Peter M. Ward. Austin: University of Texas, 2004, pp. 2-7.

8. Jorge Dominguez, and Rafael Fernandez de Castro. Between Partnership and Conflict: The United States and Mexico, 2nd ed. New York: Routledge, 2001.

9. Linda Arnold. "Why Pablo Parra wasn't executed: Courts and the Death Penalty in Mexico, 1797-1929.” In The Death Penalty and Mexico-U.S. Relations: Historical Continuities, Present Dilemmas: Conference Memoria. Edited by Patrick Timmons and Peter M. Ward. Austin: University of Texas, 2004, pp. 11-13.

10. Everard Meade. "Punishment and Prophylaxis: The Last Decade of the Death Penalty in Mexico City, 1920-1931.” Paper presented at the annual meeting of the The Law and Society Association, Berlin, Germany, 25 July 2007.

11. Everard Meade. "Anatomies of Justice and Chaos: The Mexican Public and the Death Penalty, 1929-1950.” In The Death Penalty and Mexico-U.S. Relations: Historical Continuities, Present Dilemmas: Conference Memoria. Edited by Patrick Timmons and Peter M. Ward. Austin: University of Texas, 2004, pp. 14-19.

12. Ginger Thompson, and Antonio Betancourt. "Hundreds of Thousands in Mexico March Against Crime.” The New York Times, 24 June 2006. http:/www.nytimes.com/2004/06/28/world/ hundreds-of-thousands-in-mexico-march-against-crime.html. 
13. Tracy Wilkinson. “Mexico’s drug war: Some in Mexico want to legalize the death penaltylatimes.com.” Los Angeles Times, 5 December 2008. http://www.latimes.com/news/nationworld/ world/la-fg-mexdeath5-2008dec05,0,6473286.story.

14. Arvisu, Alejandrina, and Adrian Cerda. "Debe aplicarse la pena de MUERTE?” Contenido 549 (2009): 24-32.

15. Cindy Wooden. "CNS STORY: Pope urges Mexico to respect life, praises abolition of death penalty.” Catholic News Service. Available online: http://www.catholicnews.com/data/stories/ cns/0903163.htm (accessed on 15 March 2013).

16. Sarah Ray. "Domesticating International Obligations: How to Ensure U.S. Compliance with the Vienna Convention on Consular Relations.” Sarah Ray California Law Review 91 (2003): 1731-71.

17. Michael Fleishman. "Reciprocity Unmasked: The Role of the Mexican Government in Defense of Its Foreign Nationals in United States Death Penalty Cases.” Arizona Journal of International and Comparative Law 20 (2003): 359-407.

18. Mario Benjamin Murphy, Petitioner-appellant, v. J.d. Netherland, Warden, Respondent-Appellee. United Mexican States, Amicus Curiae United States Court of Appeals, 116 F.3d (4th Cir. 1997).

19. Miguel Angel Flores, Petitioner-Appellant, v. Gary L. Jonson, Director, Texas Department of Criminal Justice, Institutional Division. Respondent-Appelleem, 210 F.3d 456 (5th Cir. 2000).

20. Ward Ferdinandusse. "Out of the Black-Box? The International Obligation of State Organs." Brooklyn Journal of International Law 29 (2003): 45.

21. International Debates. "Periodical Capital Punishment.” International Debates 2 (2004): 33.

22. Sean Murphy. United States Practice in International Law. Cambridge: Cambridge University Press, 2002.

23. United Nations. Summaries of Judgments, Advisory Opinions, and Orders of the International Court of Justice, 1997-2002. New York: United Nations, 2003.

24. International Debates. “Avena and Other Mexican Nationals.” International Debates 2 (2004): $40-41$.

25. "Mexico Seeks to Halt Executions of 51 in U.S.” The New York Times, 22 January 2003. http://www.nytimes.com/2003/01/22/world/mexico-seeks-to-halt-executions-of-51-in-us.html.

26. William Buckley. “Enter The Hague.” National Review 56 (2004): 58.

27. Nicole Aeschleman. "The Vienna Convention on Consular Relations: Quo Vadis, America." Santa Clara Law Review 45 (2005): 937-80.

28. “Offender Search List.” GlassFish Server 3.0.1-Server Running. Available online: http://www.latimes.com/news/nationworld/world/la-fg-mexdeath5-2008dec05,0,6473286.story (accessed on 18 March 2013).

29. Alan Macina. "Avena \& Other Mexican Nationals: The Litmus for Lagrand \& the Future of Consular Rights in the United States.” California Western International Law Journal 34 (2003): 115-43.

30. Mani Sheik. "From Breard to Medellin: Supreme Court Inaction or ICJ Activism in the Field of International Law?” California Law Review 94 (2006): 531-73.

31. Roig-Franzia, Manuel. "Mexican National Executed in Texas.” Washington Post, 6 August 2008. http://www.washingtonpost.com/wp-dyn/content/article/2008/08/06/AR2008080600007.html.

32. Andrew McCarthy. “Bush Dead Wrong on Medellin Case.” Human Events 27 (2007): 1-20. 
33. Marc Lacey. “Ruling Faults U.S. Execution of Mexican.” The New York Times, 20 January 2009. http://query.nytimes.com/gst/fullpage.html?res=940CE3DA1E3BF933A15752C0A96F9C8B63.

34. Steve Charnovitz. “Correcting America's Continuing Failure to Comply with the Avena Judegement.” American Journal of International Law 106 (2012): 572-81.

35. Penny Venetis. "Making Human Rights Treaty Law Actionable in the United States: The Case for Universal Implementing Legislation.” Alabama Law Review 63 (2011): 97-113.

36. David Sloss. "Executing Foster v. Neilson: The Two-Step Approach to Analyzing Self-Executing Treaties.” Harvard International Law Journal 53 (2012): 135-56.

37. Noah Moss. "Don’t Mess With Texas: Garcia v. Texas and the Supreme Court's Inversion of the Supremacy Clause.” Loyola University Chicago International Law Review 9 (2012): 347-425.

38. Rebecca Sklar. "Executing Equity: The Broad Judicial Discretion to Stay the Execution of Death Sentences.” Hofstra Law Review 40 (2012): 771-853.

39. Peter Ward, and Patrick Timmons. "Introduction: Conference Purpose.” In The Death Penalty and Mexico-U.S. Relations: Historical Continuities, Present Dilemmas: Conference Memoria. Edited by Patrick Timmons and Peter M. Ward. Austin: University of Texas, 2004, p. 1.

40. J. Richard Broughton. "Crime and Punishment: The Modern Development of Homegrown Creative Justice: Federalism, Harm, and the Politics of Leal Garcia v. Texas.” Syracuse Law Review 62 (2012): 199-206.

41. Ariane DeVogue. "Mexican National Set for Execution in Texas Despite Obama's Pleas for Delay.” ABC News, 6 July 2011. http://abcnews.go.com/Politics/mexican-national-set-executiontexas-obamas-pleas-delay/story?id=14002386.

42. Kate O’Beirne. “Like a Good Neighbor?” National Review 56 (2004): 26-27.

43. Terrence Jeffrey. "Shut Mexico's Sanctuary for Murderers.” Human Events 59 (2003): 8.

44. Jorge Dominguez, and Rafael Fernandez de Castro. Between Partnership and Conflict: The United States and Mexico, 2nd. ed. New York: Routledge, 2001.

45. Patrick Timmons. "Seed of Abolition:Experience and Culture in the Desire to End Capital Punishment in Mexico, 1841-1857.” In The Cultural Lives of Capital Punishment: Comparative Perspectives. Edited by Austin Sarat, and Christian Boulanger. California: Stanford University Press, 2005, pp. 77-114.

46. J. Michael Olivero, Gary Mounce, and Arminda Morgado. “Corrections in Mexico.” American Jails 5 (1991): 130-37.

47. Aeschleman, Nicole. "Comment: The Vienna Convention on Consular Relations: Quo Vadis, America.” Santa Clara Law Review 45 (2005): 937-56.

48. Adam Liptak. "Mexico Awaits Hague Ruling on Citizens on Death Row.” The New York Times, 15 January 2004. http://www.nytimes.com/2004/01/16/us/mexico-awaits-hague-ruling-oncitizens-on-death-row.html?pagewanted=all\&src=pm (accessed on 15 March 2013).

49. Mike Parker. "Sheriff's Obligations and the Rights of Newly Arrested Foreign Nationals." Sheriff 63 (2011): 13-17.

50. Hans von Spakovsky. “Team Obama’s Immigration Hypocrisy.” Fox News, 13 December 2011. http://www.foxnews.com/opinion/2011/12/13/team-obamas-immigration-hypocrisy/.

51. Thomas J. Keila, and Gennaro Vito. "Fear of crime and attitudes toward capital punishment: A structural equations model.” Justice Quarterly 8 (1991): 447-64. 
52. Orin Kerr. "Public Opinion on the Death Penalty-And Violent Crime Rates.” The Volokh Conspiracy, 10 January 2013. http://www.volokh.com/2013/01/10/public-opinion-on-the-deathpenalty-and-violent-crime-rates/.

53. Daniel Griswold. “Unfounded Fear of Immigrant Crime Grips Arizona.” Cato Institute. Available online: http://www.cato.org/publications/commentary/unfounded-fear-immigrant-crime-gripsarizona (accessed on 18 March 2013).

54. PublicEye.org - The Website of Political Research Associates. "PublicEye.org-The Website of Political Research Associates.” Available online: http://www.publiceye.org/ark/immigrants/ CriminalIssue.html (accessed on 15 March 2013).

56. Neema Vedadi. "Kennewick Council Candidate: Illegal Immigrants Should Get Death Penalty.” Keprtv.com, 10 August 2011. http://www.keprtv.com/news/local/127495733.html.

57. Rubén Rumbaut. "Immigration Enforcement and Civil Liberties: The Role of Local Police." Undocumented Immigration and Rates of Crime and Imprisonment: Popular Myths and Empirical Realities. National Conference, Police Foundation. University of California, Irvine-Department of Sociology, Washington, DC, USA, 21 August 2008.

58. Stephen Gibbs. "Mexico to rethink death penalty." BBC News, 23 January 2009. http://news.bbc.co.uk/2/hi/americas/7846249.

59. Ben Brown, Reed Benedict, and Kevin Buckler. "Support for the Death Penalty in Developing Democracies: A Binational Comparative Case Study.” International Criminal Justice Review 20 (2010): 398-416.

60. “Mexicans Support Status Quo on Social Issues.” Angus Reid Public Opinion. Available online: http://www.angus-reid.com/polls/13859/mexicans_support_status_quo_on_social_issues/ (accessed on 18 March 2013).

61. Tracy Wilkinson. "Some in Mexico want to legalize the death penalty-latimes.com." Los Angeles Times, 5 December 2008. http://www.latimes.com/news/nationworld/world/la-fgmexdeath5-2008dec05,0,6473286.story.

62. "HANDS OFF CAIN against death penalty in the world." HANDS OFF CAIN against death penalty in the world. Available online: http://www.handsoffcain.info/bancadati/schedastato. php?idstato=17000490 (accessed on 18 March 2013).

63. "U.S. bishops to launch major new campaign to abolish death penalty." Salt of the Earth, October 2008. http://salt.claretianpubs.org/sjnews/2005/03/sjn0503c.html.

64. “Continued Majority Support for Death Penalty”. Research Report, Ethics Newsline, 9 January 2012. Institute for Global Ethics: Promoting Ethical Action in a Global Context. http://www.globalethics.org/newsline/2012/01/09/death-penalty-4/.

65. "Death Penalty and California." Death Penalty Focus, 22 January 2013. http://www.deathpenalty.org/article.php?class=20\&list=class\&offset=1\&qty=300.

66. “Atkins v. Virginia." Capital Punishment in Context. Available online: http://www.capitalpunishmentincontext.org/resources/casesummaries/atkins (accessed on 15 March 2013).

67. “Roper v. Simmons.” Capital Punishment in Context. Available online: http://www.capitalpunishmentincontext.org/resources/casesummaries/roper (accessed on 15 March 2013). 
68. Mark Warren. “Foreign Nationals, Part II.” Death Penalty Information Center. Available online: http://www.deathpenaltyinfo.org/foreign-nationals-part-ii\#scheduled (accessed on 15 March 2013).

69. Ross Ramsey. "UT/TT Poll: Texans Stand Behind Death Penalty.” The Texas Tribune, 24 May 2012. http://www.texastribune.org/2012/05/24/uttt-poll-life-and-death/.

70. Peter Malof. "Report: Death Penalty Applied Haphazardly in Texas.” Public News Service, 12 December 2012. http://www.publicnewsservice.org/index.php?/content/article/29783-1.

71. James Olivero. “U.S. Prisons in Border Prisons in Tamaulipas, Mexico.” Rio Bravo 14 (1991): 106-22.

72. James Olivero “The Crisis in Mexican Prisons: The Impact of the United States.” In Comparing Prison Systems: Toward a Comparative and International Penology. Edited by Ralph Weiss and Nigel South. Amsterdam: Gordon and Breach Publishers, 1992, pp. 37-55.

73. David Agren. "CNS STORY: Mexican Catholics: Religiosity with disconnect between faith, practice.” Catholic News Service. Available online: http:/www.catholicnews.com/data/ stories/cns/1200688.htm (accessed on 15 March 2013).

74. Tim Merrill, and Ramon Miro. “Mexico.” Country Studies. Available online: http://countrystudies.us/mexico/ (accessed on 18 March 2013).

(C) 2013 by the author; licensee MDPI, Basel, Switzerland. This article is an open access article distributed under the terms and conditions of the Creative Commons Attribution license (http://creativecommons.org/licenses/by/3.0/). 